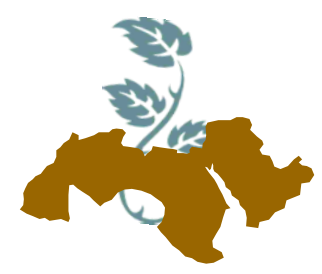

\title{
PROTECTIVE EFFECTS OF RED PALM OIL AND SUPER RED PALM OLEIN ON HYPERCHOLESTEROLEMIC RATS
}

\author{
Huda H.I. Mohammed ${ }^{1}$, Magda H. Alaam ${ }^{2}$, Nessrien M.N. Yasin ${ }^{2}$ \\ and Hafez ${ }^{1}$ S.A. \\ 1- Special Food and Nutrition Dept., Food Technology Research Institute, Agric. Research \\ Center, Giza, Egypt \\ 2- Food Science Dept., Fac. of Agric., Ain Shams Univ., P.O. Box 68 Hadayek Shoubra, 11241, \\ Cairo, Egypt
}

Keywords: Red palm oil; Super red palm olien; Hypercholesterolemia; Lipid profile; MDA; GPXs

\section{ABSTRACT}

The present work was conducted to study the effect of red palm oil (RPO) and super red palm olien (SRPOL) on the nutritional parameters of rats suffering from hypercholesterolemic. The vitamins $(\mathrm{E}, \mathrm{A}, \mathrm{D}$ and $\mathrm{K}$ ) and $\beta$ carotene were determinate by HPLC and indicated that RPO and SRPOL are considered the richest vegetable oils of antioxidant specially $\alpha$ - tocopherol and $\beta$ carotene. Thirty male rats weighting approximately 210 grams were divided into five groups, each group containing six rats. Group G1 fed on basal diet as a control negative group. Group G2 fed on basal diets containing $2 \%$ of cholesterol as a control positive group and the other groups G3, G4 and G5 fed on the same diet used in group $G 2$, yet the corn oil was replaced by RPO in G3 and SRPOL in G4, Meanwhile, group G5 was fed on the same diet used in group G2 and supplemented with a drug contained Lipitor Atorvastatin $(20 \mathrm{mg} / \mathrm{Kg}$ BW rat daily by stomach tube). Concerning biological evaluation all the studied dietary oils compared to positive control group caused an decreases in serum LDL-C and TC and significantly increased HDL-c over the feeding period of experimental rat groups, thereby decreased the TC/HDL-C and LDL-C/HDL-c ratios. Aspartate transaminase (AST), alanine transaminase (ALT) enzymes and albumin in rats serum were generally decreased by RPO, SRPOL and drug Lipitor compared to positive control group.
Also urea, creatnine and uric acid levels in rats serum were significantly decreased by the studied oils and drug. However, a significant increment in the activities of glutathione peroxidase (GPXs), catalase and total antioxidant were observed in blood of hypercholesterolemic rats treated with RPO, SRPOL and drug. As such, the treated groups showed a significant decrement in malondialdehyde (MDA) in plasma.

\section{INTRODUCTION}

Cardiovascular diseases (CVD) including coronary heart disease and stroke are the leading cause of mortality in developing countries, accounting for roughly $20 \%$ of all worldwide deaths per year. Therefore, hypercholesterolemia and its associated CVD represent one of the greatest worldwide economic, social and medical challenges that we are facing now. The large majority of epidemiological studies have demonstrated that elevated plasma triglycerides and/or reduced plasma HDL-C concentrations are associated with increased cardiovascular risk (Rahman et al 2012).

Red Palm oil (RPO) is a vegetable oil from the fruit of the palm tree (Elaeis guineensis), which originated in West Africa and is now widespread throughout the tropical areas of America and South East Asia. From the seeds of the palm tree, another vegetable oil (palm kernel oil) is obtained, which has a composition different from that of palm oil (PO) and is mainly used for non-food applications. (Fattore and Fanelli 2013). 
RPO has similar fatty acid composition as PO and is obtained by modifying the processing techniques of the crude palm oil which involve pretreatment followed by molecular distillation to produce deacidified and deodorized oil that retains as much as $80 \%$ of the original carotenoids in addition to a large amount of vitamin E (Sambanthamurthi et al 2000)

Red palm oil gets its characteristics dark red color, which comes from carotenes such as alphacarotene, beta-carotene and lycopene. The same nutrient that give tomatoes, carrots and other fruits and vegetable their rich colors. Crude palm oil is considered to be the richest natural source of carotenoids also enhance immune function by a variety of mechanisms, and can improve cardiovascular health. Carotenoids also play an important potential role by acting as biological antioxidants, protecting cells and tissues from the damaging effect of free radicals. Red palm oil is a form of processed palm oil retains $80 \%$ of the original carotenoids, making it a remarkable source of Vitamin A. (Sutapa and Analava 2009).

Mancini et al (2015) also reported that RPO was the richest natural source of carotenoids (500-700 ppm), tocopherols and tocotrienols (600-1200 ppm), all contributing to its stability and nutritional properties. Their antioxidant properties, exerted mainly against reactive oxygen species (ROS), play a role in aging, CVD and in cancer prevention.

Crude palm oil contains small quantities of ubiquinones of which coenzyme Q10 (CoQ10) is the most common. Although it is present at relatively low concentrations in crude palm oil, CoQ10 has been reported to boost the immune system, relieve angina and offers protection against heart disease and reduction of high blood pressure (Nagendran et al 2000).

Mamat et al (2005) reported that palm oil is a semi-solid fat at room temperature and can be easily separated into two fractions by partial crystallization in a liquid phase. To produce a quality edible oil, the refined product is required to undergo fractionation to separate oil into two fractions, namely olein (liquid fraction) and stearin (solid fraction). Fractionation is based on the difference of melting points of triacylglycerides. There are three types of fractionation process, namely dry, solvent and detergent fractionation. The dry fractionation is the simplest and most economical separation technique. In this process, the oil as such is partially crystallized by fractionating the melt in a controlled manner at the desired temperature, after which the remaining liquid is separated from the solid fraction by means of a vacuum filter or membrane filter press.

This work was carried out to investigate the effects of the liquid fraction red palm oil (RPO) and super red palm olien (SRPOL) diets in hypercholesterolemic rats compared to commercial drug (Lipitor).

\section{MATERIALS AND METHODS}

Oil samples: A representative sample of red palm oil (RPO) was imported from the Carotino SDN BHD Company, Malaysia. Super red palm olein (SRPOL) was obtained by dry fractionation process; RPO was placed in a beaker and initially heated in a thermally controlled water bath for 30 $\min$ at $70^{\circ} \mathrm{C}$ to melt the oil completely. The temperature was then reduced to $30^{\circ} \mathrm{C}$ within one hour followed by reducing temperature to $15^{\circ} \mathrm{C}$ within 30 min. Once the oil reached the desired temperature $\left(15^{\circ} \mathrm{C}\right)$, it was allowed to crystallize during $24 \mathrm{hr}$. The oil was fractionated using vacuum filtration to a liquid (super red palm olein) and solid fractions (palm mid fraction) according to Prasanth Kumar \& Gopala Krishna (2014). Refined, bleached and deodorized corn oil without antioxidants was obtained from Savola Company for Edible Oils, $10^{\text {th }}$ of Ramadan City, Sharkia Governate, Egypt. Lipitor Atorvastatin was purchased from pharmacy.

Animals: The animals used in this study were adult male albino rats, weighted between 208-211 grams, which were obtained from Animal Experimental House of the Res. Institute of Ophthalmology, Giza, Egypt.

Kits: Total cholesterol, high density lipoprotein cholesterol (HDL-C), triglycerides, aspartate transaminase (AST), alanine transaminase (ALT), albumin, creatinine, urea and uric acid kits were obtained from Spectrum Diagnostics, Egyptian Company for Biotechnology (S.A.E) Obour city industrial area. Cairo. Egypt. Total antioxidant, malondialdehyde (MDA), glutathione peroxidase (GPXs) and catalase were obtained from Biodiagnostic Co., Dokki, Giza, Egypt.

\section{HPLC analysis}

Determination of vitamins A, E, D and K: Five grams of sample was mixed with $0.5 \mathrm{gm}$ of ascorbic acid, $40 \mathrm{ml}$ of methanol and $10 \mathrm{ml}$ of potassium hydroxide (25\%) and heated at reflux with stirring 
for $30 \mathrm{~min}$, the mixture was cooled in an ice bath and quantitatively transferred to a separating funnel with $50 \mathrm{ml}$ water, $10 \mathrm{ml}$ methanol and $50 \mathrm{ml}$ hexane. The separating funnel was shaken vigorously for 2 min and the phases allowed to separat.

The aqueous phase was removed and extracted twice with $20 \mathrm{ml}$ portions of hexane. The hexane extracts were combined, washed three times with $100 \mathrm{ml}$ of water and then made to $100 \mathrm{ml}$ with hexane. Ten $\mathrm{ml}$ of the hexane solution was then transferred to a glass tube and the solvent was removed under a flow of nitrogen at room temperature. The residue was reconstituted with $1.0 \mathrm{ml}$ of methanol and filtered through a $13 \mathrm{~mm} 0.45 \mu \mathrm{m}$ Teflon filter disc into vial for analysis by HPLC.

HPLC were equipped with a variable wave length detector (330 nm for Vit. A, 292 for Vit E, 266 for Vit D and $280 \mathrm{~nm}$ for Vit. K) with a waters series 2695 quaternary solvent delivery system with a cooled auto sampler at $4^{\circ} \mathrm{C}$ and heated column compartment set at $30^{\circ} \mathrm{C}$. The compounds were separated on a $10 \mu \mathrm{m}$ Bondclone $3.9 \times 300$ mm C18 column (phenomenex, Sydney, Australia) fitted with a $\mathrm{C} 18$ guard column. The mobile phase consisted of water: methanol $(5: 95)$, at a flow rate of $1 \mathrm{ml} / \mathrm{min}$. according to the method described by Plozza et al (2012).

Determination of $\boldsymbol{\beta}$ carotene: $\beta$ carotenoid extracts were saponified prior to their HPLC analysis by method proposed by $\mathbf{N g}$ and Tan (1988). The mobile phase was a ternary mixture of acetonitrile: methanol: 1,2-dichloroethane $(60: 35: 5, \mathrm{v} / \mathrm{v} / \mathrm{v})$ to which $0.1 \%$ BHT, $0.1 \%$ triethylamine and $0.05 \mathrm{M}$ of ammonium acetate (in methanol) was added. The compounds were separated on a $\mathrm{C} 18$ column (2504.6 mm id., Vydac) with a guard-column Alltima C18 $5 \mu \mathrm{m}$ (7.54.6 mm id., Alltech). The column was kept at room temperature (about $22^{\circ} \mathrm{C}$ ) and the flow rate was $1 \mathrm{ml} \mathrm{min}^{-1}$. The wavelength was adjusted to $450 \mathrm{~nm}$. The peak areas were measured using a Millennium Software v. 2.0 (Waters).

Biological experiment: Thirty male albino rats were housed individually in air cages with screen bottoms. The rats were adapted for seven days. They were fed basal diet. The basal diet was formulated according to AOAC (2010), it consisted of $15 \%$ protein (casein), $65 \%$ starch, $10 \%$ corn oil, $5 \%$ cellulose, $4 \%$ minerals mixture, and $1 \%$ vitamins mixture. The animals were then divided into five major groups each group contained 6 rats: Negative control group (G1), rats fed on a basal diet until the end of experiment. The remained 24 rats were fed on high cholesterol diet supplemented with $2 \%$ cholesterol for 2 weeks before the starting of the experiment and during the 6 weeks (the end of experiment). After hypercholesterolemia induction ( 2 weeks); 6 rats out of 24 hypercholesterolemia rats were considered as positive control group (2). The remainder hypercholesterolemia rats were subdivided randomly into three groups (G3, G4 and G5) as treated hypercholesterolemia groups: G3 and G4 were fed on hypercholesterolemia diets each contained $10 \%$ of RPO and SRPOL instead of corn oil; respectively. Meanwhile, G5 was fed on hypercholesterolemia diet and $20 \mathrm{mg}$ Lipitor/Kg BW rat/day. Formulated diets and water were administrated ad- libitum except $\mathrm{G} 5$, the drug was administrate by stomach tube for other 6 weeks.

Feeding was continued for 8 weeks during which each rat was weighted at the beginning of experimental period and after 7 days intervals. Blood samples were taken and centrifuged at 3000 rpm for $15 \mathrm{~min}$. and the obtained serum samples were used for the biochemical analysis: total cholesterol (Allain et al 1974), HDL-c (Lopez-Virella et al 1977), LDL-c (Friedewald et al 1972), AST and ALT (Reitman and Frankel, 1957), albumin (Doumas et al 1971), urea (Fawcet and Scott 1960)., creatinine (Hare, 1950), and uric acid (Barham \& Trinder, 1972).. Another blood specimens were taken into heparinized tubes as anticoagulation as described by Schermer, (1967), and kept frozen at $-20^{\circ} \mathrm{C}$ till the following biochemical analysis: GPXs (Paglia \& Valentine, 1967), plasma catalase (Aebi, 1984), malondialdehyde (Satoh, 1978), and total antioxidant capacity (Koracevic et al 2001). At the end of experimental period, the internal organs (liver, kidney, heart and aorta) were separated, weighted and corresponded to their body weight.

Statistical analysis: The obtained data were exposed to Statistical Analysis User's Guide (SAS, 1995). Duncan's multiple range test at $5 \%$ level of significance was used for comparison between means.

\section{RESULTS AND DISCUSSION}

Identification of vitamins and $\boldsymbol{\beta}$ carotene: The results in Table 1 showed that SRPOL had higher content of vitamins $E$ ( $\alpha$ tocopherol), A,D, K and $\beta$ carotene by quantities accounted to $643.18,4.00$, 2.54, 202.43 and $981.2 \mathrm{ppm}$, respectively, than in RPO by wide difference being $413.72,1.88,0.83$, 
54.04 and $784.94 \mathrm{ppm}$, respectively. It was noticed that SRPOL and RPO are considered to be the richest natural source of antioxidants especially $\alpha$ tocopherol and $\beta$ carotene. The RPO is an unconventional oil produced from crude palm oil (CPO) through a new process in which the deacidification and deodorization are carried out using molecular distillation under milder conditions. This preserves more than $80 \%$ of each of the carotenoids, tocopherols and tocotrienols, unlike in conventional refining where all the carotenoids are destroyed. $\mathrm{RPO}$ is therefore the first physically refined vegetable oil rich in natural carotenoids, tocopherols and tocotrienols (El-Hadad et al 2010).

Table 1. Vitamins and $\beta$-carotene content (ppm) of red palm oil and its fractions

\begin{tabular}{|c|c|c|}
\hline \multirow{2}{*}{ Vitamins } & \multicolumn{2}{|c|}{ Oil } \\
\cline { 2 - 3 } & RPOL & SRPOL \\
\hline Vitamin E ( $\alpha$ tocopherol) & 413.72 & 643.18 \\
Vitamin A & 1.88 & 4.00 \\
Vitamin D & 0.83 & 2.54 \\
Vitamin K & 54.04 & 202.43 \\
B-Carotene & 784.94 & 981.2 \\
\hline
\end{tabular}

Growth Performance: the effect of RPO, SRPOL and the drug Lipitor Atorvastatin on mean body weight (BW) and calculated gain in body weight of normal and hypercholesterolemia rats are present in Table 2. The data showed a gradual increase in body weight of all animals with advancing the experimental period. It was cleared that there was no significant $(p<0.05)$ difference between the mean body weight of all groups except the group treated with RPO (G3) which lead to significant $(p<0.05)$ increase in mean body weight compared to the negative control one. However, after 6 weeks it was noticed that the growth performance of rats showed not significant $(\mathrm{p}<0.05)$ difference. Animals growth treated with RPO (G3) were in the first order followed by rats treaded with SRPOL (G4), drug Lipitor (G5) then the positive and negative control groups (G2 and $G 1$, respectively). These results are in agreement with Dauqan et al (2011).

Internal organ: The results in Table (3) show the average of internal organ weight and their relative values, expressed on body weight basis of rats fed for six weeks on hypercholesterolemia diet and diets treated with RPO, SRPOL and drug Lipitor compared to those of rats fed on corn oil (negative control) and fed on hypercholesterolemia diet only (positive control). Data showed that all rats fed on any diet had the same statistically $(p<0.05)$ mean weight of their kidney and heart as well as their relative weight to body weight being similar to those of rat groups fed on negative and positive control diets. Meanwhile, the relative weight of liver was significantly $(p<0.05)$ decreased of all groups compared to positive control group. The high weight of liver appeared in positive control group due to the accumulation of cholesterol whereas, feeding cholesterol disturbed hepatic lipid metabolism in rats.

Table 2. Mean body weight (BW) and body weight gain (BWG) of hypercholesterolemia rats fed for 6 weeks on diets containing $10 \%$ of studied oil

\begin{tabular}{|c|c|c|c|c|c|c|c|c|c|c|}
\hline \multirow{2}{*}{ Treatment } & \multicolumn{9}{|c|}{ BW (g) after period in weeks } & \multirow{2}{*}{$\begin{array}{c}\text { BWG } \\
(\mathrm{g})\end{array}$} \\
\hline & 0 & 1 & 2 & 3 & 4 & 5 & 6 & 7 & 8 & \\
\hline $\mathrm{N}$ - control G 1 & $208.75^{a}$ & $207.52^{b}$ & $213.28^{b}$ & $219.00^{b}$ & $234.75^{\mathrm{b}}$ & $240.50^{b}$ & $246.00^{b}$ & $255.07^{b}$ & $271.75^{\mathrm{b}}$ & $63.00^{\mathrm{a}}$ \\
\hline P- control G 2 & $210.15^{a}$ & $218.65^{\mathrm{ab}}$ & $224.00^{\mathrm{ab}}$ & $237.15^{\mathrm{ab}}$ & $249.69^{\mathrm{ab}}$ & $254.53^{\mathrm{ab}}$ & $260.05^{a b}$ & $278.25^{a}$ & $279.57^{\mathrm{ab}}$ & $69.42^{\mathrm{a}}$ \\
\hline G 3 & $211.26^{a}$ & $241.25^{a}$ & $247.00^{a}$ & $254.50^{\mathrm{a}}$ & $265.77^{a}$ & $270.25^{a}$ & $276.24^{a}$ & $287.01^{a}$ & $296.70^{\mathrm{a}}$ & $85.44^{\mathrm{a}}$ \\
\hline G 4 & $208.00^{\mathrm{a}}$ & $221.91^{\mathrm{ab}}$ & $228.41^{\mathrm{ab}}$ & $237.54^{\mathrm{ab}}$ & $250.78^{a b}$ & $256.54^{\mathrm{ab}}$ & $262.21^{a b}$ & $270.25^{\mathrm{ab}}$ & $285.25^{\mathrm{ab}}$ & $77.25^{a}$ \\
\hline G 5 & $211.67^{a}$ & $238.67^{\mathrm{ab}}$ & $244.50^{a}$ & $252.60^{a}$ & $262.80^{\mathrm{a}}$ & $267.66^{a}$ & $270.32^{\mathrm{ab}}$ & $276.08^{\mathrm{ab}}$ & $283.75^{\mathrm{ab}}$ & $72.08^{a}$ \\
\hline
\end{tabular}

Means with the same letters in the same vertical column are not significantly different at $5 \%$ level 
Table 3. Mean internal organs weights $(\mathrm{g})$ and their relative weights (\%) of hypercholesterolemia rats fed for 6 weeks on diets containing $10 \%$ of studied oils

\begin{tabular}{|c|c|c|c|c|c|c|c|}
\hline \multirow{2}{*}{ Treatment } & Final body weight & \multicolumn{2}{|c|}{ Liver } & \multicolumn{2}{c|}{ Kidney } & \multicolumn{2}{c|}{ Heart } \\
\cline { 2 - 8 } & $\mathbf{( g )}$ & $\mathbf{( g )}$ & $\%$ & $\mathbf{( g )}$ & $\%$ & $\mathbf{( g )}$ & $\%$ \\
\hline N- control G 1 & $271.75^{\mathrm{b}}$ & $6.75^{\mathrm{b}}$ & $2.48^{\mathrm{b}}$ & $1.42^{\mathrm{a}}$ & $0.52^{\mathrm{a}}$ & $1.05^{\mathrm{a}}$ & $0.39^{\mathrm{a}}$ \\
P- control G 2 & $279.57^{\mathrm{ab}}$ & $8.72^{\mathrm{a}}$ & $3.13^{\mathrm{a}}$ & $1.40^{\mathrm{a}}$ & $0.50^{\mathrm{a}}$ & $1.20^{\mathrm{a}}$ & $0.43^{\mathrm{a}}$ \\
G 3 & $296.70^{\mathrm{a}}$ & $7.12^{\mathrm{b}}$ & $2.38^{\mathrm{b}}$ & $1.45^{\mathrm{a}}$ & $0.49^{\mathrm{a}}$ & $1.35^{\mathrm{a}}$ & $0.45^{\mathrm{a}}$ \\
G 4 & $285.25^{\mathrm{ab}}$ & $7.27^{\mathrm{b}}$ & $2.65^{\mathrm{b}}$ & $1.37^{\mathrm{a}}$ & $0.48^{\mathrm{a}}$ & $1.50^{\mathrm{a}}$ & $0.52^{\mathrm{a}}$ \\
G 5 & $283.75^{\mathrm{ab}}$ & $7.60^{\mathrm{ab}}$ & $2.65^{\mathrm{b}}$ & $1.35^{\mathrm{a}}$ & $0.48^{\mathrm{a}}$ & $1.23^{\mathrm{a}}$ & $0.43^{\mathrm{a}}$ \\
\hline
\end{tabular}

Means with the same letters in the same vertical column are not significantly different at $5 \%$ level

Lipid profile: Data presented in Table 4 revealed that serum total cholesterol level of the negative control group (G1) which fed only on a control basal diet at the beginning of the experimental was $84.09 \mathrm{mg} / \mathrm{dl}$. At the end of the experiment, the TC level received to $87.35 \mathrm{mg} / \mathrm{dl}$ with increasing ratio by $3.88 \%$. The TC levels at the beginning of the experiment of the hypercholesterolemia rats groups (G2, G3, G4 and G5) had values ranging between 141.03 and $143.25 \mathrm{mg} / \mathrm{dl}$ with no significant difference. At the end of the experiment (after 6 weeks), the TC concentration was elevated in the serum of the positive control group (G2) which fed on high cholesterol diet from 142.59 to 181.84 $\mathrm{mg} / \mathrm{dl}$. On the other hand, the TC levels of all the treated group which fed on RPO (G3), SRPOL (G4) and the drug (Lipitor) group (G5) were decreased compered to positive and negative control groups (G2 and $\mathrm{G} 1)$ by different percentage. The final levels of serum TC were lower than the start levels descendingly by $21.56,17.98$ and $15.46 \%$ in rats fed on drug, super red palm olein and red palm oil, respectively, compared to $27.53 \%$ increase in positive control rats group.

The lowest cholesterol levels in both RPO and SRPOL (G3 and G4) dietary groups may be therefore as a result of tocotrienols and antioxidant content in there oils, potentially making RPO a good dietary oil for both human and animal health. Tocotrienols, which are found in abundance in RPO influence cholesterol synthesis by posttranscriptional suppression of hydroxy methyl glutaryl-coenzyme A reductase (HMG-CoA), the rate limiting step in endogenous cholesterol synthesis, suppressing liver cholesterol synthesis as found by Jeger and Dieterle, (2012).

Table 4. Serum TC (mg/dl), HDL - c (mg/dl) and LDL- c $(\mathrm{mg} / \mathrm{dl})$ in hypercholesterolemia rats fed for 6 weeks on diets containing $10 \%$ of studied oils

\begin{tabular}{|c|c|c|c|c|c|c|}
\hline \multirow{2}{*}{ Treatments } & \multicolumn{2}{|c|}{ TC (mg/dl) } & \multicolumn{2}{c|}{ HDL - c (mg/dl) } & \multicolumn{2}{c|}{ LDL- c (mg/dl) } \\
\cline { 2 - 7 } & \multicolumn{2}{c|}{$\begin{array}{c}\text { Feeding period } \\
\text { (weeks) }\end{array}$} & \multicolumn{2}{c|}{$\begin{array}{c}\text { Feeding period } \\
\text { (weeks) }\end{array}$} & \multicolumn{2}{c|}{ Feeding period (weeks) } \\
\cline { 2 - 7 } & Zero & $\mathbf{6}$ & Zero & $\mathbf{6}$ & Zero & 6 \\
\hline N- control G 1 & $84.09^{\mathrm{b}}$ & $87.35^{\mathrm{e}}$ & $43.96^{\mathrm{a}}$ & $44.70^{\mathrm{a}}$ & $24.00^{\mathrm{b}}$ & $26.04^{\mathrm{d}}$ \\
P- control G 2 & $142.59^{\mathrm{a}}$ & $181.84^{\mathrm{a}}$ & $32.51^{\mathrm{b}}$ & $27.16^{\mathrm{d}}$ & $65.85^{\mathrm{a}}$ & $137.62^{\mathrm{a}}$ \\
G 3 & $143.25^{\mathrm{a}}$ & $121.10^{\mathrm{b}}$ & $32.58^{\mathrm{b}}$ & $35.15^{\mathrm{c}}$ & $66.98^{\mathrm{a}}$ & $67.95^{\mathrm{b}}$ \\
G 4 & $141.03^{\mathrm{a}}$ & $115.67^{\mathrm{c}}$ & $32.03^{\mathrm{b}}$ & $39.46^{\mathrm{b}}$ & $65.18^{\mathrm{a}}$ & $58.61^{\mathrm{c}}$ \\
G 5 & $142.70^{\mathrm{a}}$ & $111.93^{\mathrm{d}}$ & $32.89^{\mathrm{b}}$ & $33.84^{\mathrm{c}}$ & $66.49^{\mathrm{a}}$ & $61.08^{\mathrm{c}}$ \\
\hline
\end{tabular}

Means with the same letters in the same column are not significantly different at $5 \%$ level. 
A strong inverse relation between HDL- $c$ and risk of $\mathrm{CHD}$ has been advocated. HDL particles control the lipid metabolism by taking free cholesterol from the peripheral tissue cells, etherifying it and deposit it in the liver for catabolism and from which a portion of cholesterol is put back into circulation and another portion is excreted after conversion to bile acids. This is important to reduce risk for CVD and hypertension. The obtained results illustrated in Table 4 revealed that the serum HDLcholesterol level of the negative control group (G1) which fed only on a control basal diet was 43.96 $\mathrm{mg} / \mathrm{dl}$ which slightly increased at the end of the experiment to be $44.70 \mathrm{mg} / \mathrm{dl}$ by $1.68 \%$. The levels of plasma HDL-C in hypercholesterolemia rat groups at the beginning were statistically $(p<0.05)$ equal being in the range between $32.03 \mathrm{mg} / \mathrm{dl}$ and $32.89 \mathrm{mg} / \mathrm{dl}$. At the final of the experiment after 6 weeks, the HDL-c level in serum of the positive control group (G2) which fed on high cholesterol diet significantly decreased by percentage of $16.46 \%$. while, the understudying oils and the drug, significantly $(p<0.05)$ increased the serum HDL-c levels of rat groups G3, G4 and G5. SRPOL was the most effective oil on improving the serum HDL- c level followed by RPO and the drug (Lipitor) by percentages of $23.20 \%, 7.89$ and $2.89 \%$, respectively at the end of the experiment.

From the same Table 4 it could be noticed that the calculated plasma LDL-c of rats fed diets contained $10 \%$ of the tested oils and the drug or positive and negative control diets followed the same trend that did the TC. The results showed, a significant $(p<0.05)$ changes in LDL-C concentration between $\mathrm{G} 1$ and other group at the beginning of the experiment. It was $24.00 \mathrm{mg} / \mathrm{dl}$ meanwhile; it was $65.85,66.98,65.18$ and $66.49 \mathrm{mg} / \mathrm{dl}$ ,respectively. These concentrations strongly and significantly increased in positive control group by $109.00 \%$ at the end of the experiment, while the investigated oils and the drug, significantly improved the levels of serum LDL-c as compared to the positive control group (G2). Animals fed on SRPOL and the drug were in the first order with no significant difference between them followed by rats fed on RPO.

High levels of low-density lipoprotein cholesterol LDL-c are a risk factor for the onset of CVDs, as the presence of oxidized LDL-C is also involved as an early event in the pathogenesis of atherosclerosis, a condition where plaque inside the arteries may impair the blood flow and increase the risk of coronary heart disease (Shahidi \& De Camargo,
2016). Therefore, these oils had hypocholesterolemic effect, it seems probably resulting from that SRPOL and RPO are rich in natural antioxidants such as tocopherols and tocotrienols. However, the unbleached palm oil, so-called red palm olein is rich in $\alpha$ - and $\beta$-carotenes and tocotrienols which have been shown to exhibit good antioxidant properties.

Risk ratios: The previous studies revealed that an increase in plasma TC level which is usually due to an increase in the level of LDL-c ; and a decrease in HDL-c level have been independently attributed to be associated with increased risk of atheroscelerosis and CHD. However, recent reports indicated that the TC/HDL-C and LDL/HDL ratios are stronger indices of atherogenicity of lipoproteins rather than the lipid profile of the individual lipoprotein fraction (Ngondi et al 2005). The calculated ratios in Table 5 followed the same trend of those of serum TC and LDL-C during the feeding period of rat groups. At the beginning of the experiment, the TC/HDL-C and LDL-C/HDL-c risk ratios of the negative control group (G1) which fed only on a control basal diet were 1.92 and $0.55 \mathrm{mg} / \mathrm{dl}$, respectively which slightly changes throughout the experimental period being 1.95 and $0.58 \mathrm{mg} / \mathrm{dl}$ at the end of experiment. In the other groups (G2, G3, G4 and G5), each of TC/HDL-c and LDL/HDL ratios were the same (high value) at the beginning of the experiment. With advancing the period those ratios decreased in G3, G4 and G5 compared to $\mathrm{G} 2$ which increased. It was noticed that feeding on SRPOL was the most effective oil on lowering the TC/HDL-C and LDL/HDL ratios in rats serum (G4) followed by those treated by drug Lipitor (G5), while the risk ratios in rats fed on RPO (G3) were the least values. It was noticed from the calculated ratios that the consumption fed on SRPOL and RPO decreasing and protecting of the risk of CVD and atherosclerosis.

Liver enzymes: Aspartate transaminase AST and alanine transaminase ALT are enzymes catalyze the transfer of an amino group from amino acid to keto acid, one of the important general reactions of protein metabolism; a new amino and keto acids are formed in the process. These two transaminases are of clinical interest that reflect liver function. They occur in most of organs and tissues; the liver is very rich in these two enzymes. Serum transaminases levels in normal subjects are low, but after extensive tissues destruction, particularly 
in liver, these enzymes are liporated into the serum. Thus, their appearance in serum is a marker to tissue damage. They are found in the serum at very high levels during liver infection with hepatocytes (liver cirrhosis), hemorrhage and inactive hepatitis.

From Table 6 the serum AST of normal rats (G1) was $35.03 \mathrm{mg} / \mathrm{dl}$ at the beginning of experiment which was nearly the same at the end of the experimental period after 6 weeks by concentrations accounted to $39.07 \mathrm{mg} / \mathrm{dl}$. While the average levels of serum AST in hypercholesterolemia rats at the beginning of the experiment ranged between 57.11 to $58.45 \mathrm{U} / \mathrm{L}$. It was clearly noticed that feeding on the tested oil diets and drug for 6 weeks caused significant $(p<0.05)$ decreases in levels of the AST enzyme in plasma of the treated animals reaching an average levels ranging between 49.35and $54.43 \mathrm{U} / \mathrm{L}$ compared to $76.10 \mathrm{U} / \mathrm{L}$ in rats serum fed on hypercholesterolemia diet only (positive control group G2). It could be noticed that SRPOL diet and drug (Lipitor) showed the lowest serum AST concentration with no significantly $(p<0.05)$ difference between them followed by RPO diets. It was noticed that rats group fed on SRPOL diet take the first order in decreasing the level of AST enzyme followed RPO. These decreases were by $15.57,12.56$ and $6.53 \%$ from the baseline levels of the serum drug group (G5), SRPOL group (G4) and RPO group (G3) respectively. Meanwhile, AST increased by $33.25 \%$ in positive control serum rats group (G2).

Table 5. TC/HDL-C and LDL-c/HDL-c Risk ratios in hypercholesterolemia rats fed for 6 weeks on diets containing $10 \%$ of studied oils:

\begin{tabular}{|c|c|c|c|c|c|c|c|c|c|c|}
\hline \multirow{2}{*}{$\begin{array}{c}\text { Period } \\
\text { (weeks) }\end{array}$} & \multicolumn{6}{|c|}{\begin{tabular}{c} 
Risk ratios in rats fed on diets containing 10\% oils \\
\cline { 2 - 11 }
\end{tabular}} & $\begin{array}{c}\text { N- control } \\
\text { G }\end{array}$ & \multicolumn{2}{|c|}{$\begin{array}{c}\text { P-control } \\
\text { G 2 }\end{array}$} & \multicolumn{2}{|c|}{ G 3 } & \multicolumn{2}{|c|}{ G 4 } & \multicolumn{3}{|c|}{ G 5 } \\
\cline { 2 - 11 } & A & B & A & B & A & B & A & B & A & B \\
\hline $\mathbf{0}$ & 1.92 & 0.55 & 4.17 & 1.93 & 4.17 & 1.96 & 4.12 & 1.91 & 4.17 & 1.96 \\
$\mathbf{6}$ & 1.95 & 0.58 & 6.73 & 5.10 & 3.44 & 1.93 & 2.94 & 1.49 & 3.31 & 1.81 \\
\hline
\end{tabular}

A: TC/HDL-c - B: LDL-C/HDL-C

On the same trend the levels of serum ALT of hypercholesterolemia rat groups fed on the studied oils and drug (Table 6) showed a decreases from 46.26 to $38.45 \mathrm{U} / \mathrm{L}, 46.60$ to $31.88 \mathrm{U} / \mathrm{L}$ and 46.97 to $33.27 \mathrm{U} / \mathrm{L}$ in RPO, SRPOL and drug groups, respectively. These decreases were by 16.88 , 34.40 and $29.17 \%$ for the corresponding values. On contrary, there was a significant $(p<0.05)$ increase in its level in plasma of rats fed only on hypercholesterolemia diet from 46.84 to $56.92 \mathrm{U} / \mathrm{L}$ while the level of ALT enzyme of the normal rats was $25.03 \mathrm{U} / \mathrm{L}$ at the beginning of the experiment which was nearly the same (26.82 U/L) after 6 weeks. These results provide that SRPOL and drug Lipitor were the most effective on improving serum ALT followed by the RPO.

Table 6. Serum aspartate aminotransferase (AST) enzyme (U/L), alanine aminotransferase (ALT) enzyme $(\mathrm{U} / \mathrm{L})$ and albumin $(\mathrm{g} / \mathrm{dl})$ of hypercholesterolemia rats fed for 6 weeks on diets containing $10 \%$ of studied oils

\begin{tabular}{|c|c|c|c|c|c|c|}
\hline \multirow{2}{*}{ Treatments } & \multicolumn{2}{|c|}{ AST (U/L) } & \multicolumn{2}{c|}{ ALT (U/L) } & \multicolumn{2}{c|}{ Albumin (g/dl) } \\
\cline { 2 - 7 } & Feeding period (weeks) & Feeding period (weeks) & \multicolumn{2}{c|}{ Feeding period (weeks) } \\
\cline { 2 - 6 } & Zero & $\mathbf{6}$ & Zero & $\mathbf{6}$ & Zero & $\mathbf{6}$ \\
\hline N- control G 1 & $35.03^{\mathrm{b}}$ & $39.07^{\mathrm{d}}$ & $25.03^{\mathrm{b}}$ & $26.82^{\mathrm{d}}$ & $3.26^{\mathrm{a}}$ & $3.23^{\mathrm{b}}$ \\
P- control G 2 & $57.11^{\mathrm{a}}$ & $76.10^{\mathrm{a}}$ & $46.84^{\mathrm{a}}$ & $56.92^{\mathrm{a}}$ & $2.72^{\mathrm{b}}$ & $2.12^{\mathrm{c}}$ \\
G 3 & $58.30^{\mathrm{a}}$ & $54.35^{\mathrm{b}}$ & $46.26^{\mathrm{a}}$ & $38.45^{\mathrm{b}}$ & $2.62^{\mathrm{b}}$ & $3.34^{\mathrm{b}}$ \\
G 4 & $58.35^{\mathrm{a}}$ & $51.02^{\mathrm{c}}$ & $46.60^{\mathrm{a}}$ & $31.88^{\mathrm{c}}$ & $2.76^{\mathrm{b}}$ & $3.88^{\mathrm{a}}$ \\
G 5 & $58.45^{\mathrm{a}}$ & $49.35^{\mathrm{c}}$ & $46.97^{\mathrm{a}}$ & $33.27^{\mathrm{c}}$ & $2.66^{\mathrm{b}}$ & $3.96^{\mathrm{a}}$ \\
\hline
\end{tabular}

Means with the same letters in the same column are not significantly different at $5 \%$ level 
Evaluation of albumin status may be helpful in the assessment of disease progression. Albumin is an important component of plasma antioxidant activity that primarily binds free fatty acids, divalent cations and hydrogen oxychloride ( $\mathrm{HOCl})$ as found by Olorunnisola et al (2012). From the same Table 6 , serum albumin level of normal rats (G1) was $3.26 \mathrm{~g} / \mathrm{dl}$ at the beginning of the experiment which was similar to that after six weeks $(3.23 \mathrm{~g} / \mathrm{dl})$, while it was significantly decreased in the positive control group (G2) fed on hypercholesterolemia diet by percentage of $22.06 \%$ after six weeks. While, the investigated oils and the drug significantly improved (increase) the levels of serum albumin. It could be noted that SRPOL and drug diets showed the highest serum albumin concentration with not significant $(p<0.05)$ difference followed by RPO (G3) which showed an increase in serum albumin level not significantly $(p<0.05)$ difference with its level in G1. These increases were by $48.87,40.57$ and $27.48 \%$ from the baseline levels in serum rats of drug group (G5), SRPOL group (G4) and RPO group (G3), respectively, compared to $22.06 \%$ of albumin decrease in positive control serum rats group (G2).

In conclusion, the obtained results showed that the treated rats with the investigated oils and drug statistically improved serum AST, ALT and albumin levels as compared to the positive control group. This hepatoprotective role of the investigated oils may be due to its membrane stabilizing effect of hepatic cells by the valuable antioxidants, as well as anti-inflammatory effects of their polyphenolic compounds, tocotrinols and $\beta$ carotene against liver diseases associated with oxidative stress and hypercholesterolemia. These compounds may delay the rate of oxidation by directing the break- down of peroxides into stable substances that do not promote further oxidation or by sweeping free radicals away.

Kidney functions: Urea and uric acid are the principal waste products of protein catabolism. They synthesized in the liver from ammonia produced as a result of the deamination of amino acids. The rate of production is accelerated by a high protein diet or by increasing endogenous catabolism due to starvation or tissue damage. Creatinine is the major waste product of creatine metabolism by muscle. In the kidney, it is filtered by the glomerulus and actively excreted by the tubules. (Stevens et al 2006).

From Table 7 it was cleared that at the beginning of the experiment, the hypercholesterolemia diet produced significant adverse effects on the urea concentration compared to negative control group (G1). The data demonstrate that serum urea level of the normal rats (G1) was $35.47 \mathrm{mg} / \mathrm{dl}$ at the beginning of experiment which was slightly increased to $36.89 \mathrm{mg} / \mathrm{dl}$ at the end of the experimental period. While these concentrations strongly and significantly $(p<0.05)$ increased in the positive control group (G2) by $32.00 \%$ at the end of the experiment. The investigated oils significantly $(p<0.05)$ decreased the urea levels for G3 and G4, meanwhile the drug Lipitor group slightly increased its level. It was noticed that the group fed on RPO (G3) was the most effective in decreasing the urea level with no significant $(p<0.05)$ difference with negative control group (G1) followed by group fed on SRPOL (G4). These decreases were by $11.24 \%$ and $7.41 \%$ for RPO and SRPOL, respectively meanwhile, the serum urea level of the group treated with Lipitor drug (G5) was slightly increased by $4.89 \%$.

Table 7. Serum urea, creatinine and uric acid $(\mathrm{mg} / \mathrm{dl})$ of hypercholesterolemia rats fed for 6 weeks on diets containing $10 \%$ of studied oils

\begin{tabular}{|c|c|c|c|c|c|c|}
\hline \multirow{2}{*}{ Treatments } & \multicolumn{2}{|c|}{ Urea (mg/dl) } & \multicolumn{2}{c|}{ Creatinine (mg/dl) } & \multicolumn{2}{c|}{ Uric acid (mg/dl) } \\
\cline { 2 - 7 } & \multicolumn{2}{|c|}{ Feeding period (weeks) } & \multicolumn{2}{c|}{ Feeding period (weeks) } & \multicolumn{2}{c|}{ Feeding period (weeks) } \\
\cline { 2 - 7 } & Zero & $\mathbf{6}$ & Zero & 6 & Zero & 6 \\
\hline N- control G 1 & $35.47^{\mathrm{b}}$ & $36.89^{\mathrm{d}}$ & $0.48^{\mathrm{b}}$ & $0.50^{\mathrm{d}}$ & $1.15^{\mathrm{b}}$ & $1.19^{\mathrm{c}}$ \\
P- control G 2 & $45.21^{\mathrm{a}}$ & $60.10^{\mathrm{a}}$ & $1.07^{\mathrm{a}}$ & $1.19^{\mathrm{a}}$ & $1.96^{\mathrm{a}}$ & $3.09^{\mathrm{a}}$ \\
G 3 & $45.64^{\mathrm{a}}$ & $40.51^{\mathrm{cd}}$ & $1.07^{\mathrm{a}}$ & $0.80^{\mathrm{c}}$ & $2.10^{\mathrm{a}}$ & $1.35^{\mathrm{b}}$ \\
G 4 & $46.01^{\mathrm{a}}$ & $42.60^{\mathrm{c}}$ & $1.03^{\mathrm{a}}$ & $0.82^{\mathrm{bc}}$ & $2.16^{\mathrm{a}}$ & $1.45^{\mathrm{b}}$ \\
G 5 & $46.66^{\mathrm{a}}$ & $48.94^{\mathrm{b}}$ & $1.02^{\mathrm{a}}$ & $0.86^{\mathrm{b}}$ & $1.99^{\mathrm{a}}$ & $1.63^{\mathrm{b}}$ \\
\hline
\end{tabular}

Means with the same letters in the same column are not significantly different at $5 \%$ level. 
The same Table 7 showed an increases in serum creatinine level in rat group fed on hypercholesterolemia diet only (G2) by $11.21 \%$ at the end of the experiment compared to rats group fed on basal diet (G1) which was $0.48 \mathrm{mg} / \mathrm{dl}$ at the beginning of the experiment nearly equal to the mean level after 6 weeks $(0.50 \mathrm{mg} / \mathrm{dl})$. The other groups (G3, G4 and G5) showed decremental pattern with small significant $(p<0.05)$ variation in creatinine levels which were by $25.23,20.39$ and $15.69 \%$, respectively at the end of experiment. No significant $(p<0.05)$ difference was noticed in serum level between RPO and SRPOL and also between SRPOL and the drug groups.

In the same trend the Table 7 demonstrated that the investigated oils and drug significantly $(p<0.05)$ improved the level of serum uric acid in rats by percentages of $35.71,32.87$ and $18.1 \%$ for RPO, SRPOL and the drug groups, respectively at the end of the experiment, meanwhile positive control group showed strong significant increase in the level of uric acid which was by $57.65 \%$ at the end of the experiment. The increasing in uric acid may be caused by renal urate reabsorption which can be induced from decreased renal blood flow due to the decrease of glomerular filtration rate results in a slight increase of serum uric acid. Or may be attributed to impaired renal excretion of uric acid rather than uric acid overproduction (Mossa \& Abbassy 2012). However, Hyperuricemia can also be derived from increased cell apoptosis and necrosis due to inflammations.

In conclusion, the biochemical renal markers (serum urea, uric acid and creatinine) in hypercholesterolemia rats were significantly decreased as treated by the RPO, SRPOL and the drug.

In the present study, the improvement of this renal dysfunction may be attributed to the effect of antioxidants compounds present in red palm oil such as tocopherol, tocotrienol and Q10 however, the kidneys contain the highest endogenous levels of CoQ10 compared with all other organs. This is likely due to the reliance of the kidney on aerobic metabolism and high density of mitochondria. It is imperative that endogenous CoQ10 levels are maintained to ensure mitochondrial health, and this form the rationale for CoQ10 therapy. The major direct antioxidant role of CoQ10 is prevention of lipid peroxidation, and it also acts indirectly through its interactions with $\alpha$-tocopherol. (Small et al 2012).

Antioxidant activity: It was noticed from Table (8) that the level of plasma malondialdehyde (MDA) was significantly $(p<0.05)$ increased in positive control group (G2) by $44.10 \%$ and slightly increased in G5. On the other hand, the levels of MDA rats plasma fed on the investigated oils (G3 and G4) were significantly $(p<0.05)$ decreased to be $10.01 \mathrm{nmol} / \mathrm{ml}$ and $9.99 \mathrm{nmol} / \mathrm{ml}$, respectively. While the activities of blood enzymatic antioxidants (Catalase, GPXs) and non- enzymatic antioxidants (total antioxidant) were significantly $(p<0.05)$ decreased in blood of the positive control rats group (G2), meanwhile, supplemented the experimental hypercholesterolemic rat groups with RPO, SRPOL and drug Lipitor significantly $(p<0.05)$ increased enzymatic antioxidants and non- enzymatic antioxidants.

It was noticed that RPO and SRPOL were more active than the drug (Lipitor) in the improvement the antioxidant activity in rats blood. These increases in antioxidant activity may be due to vitamin $\mathrm{E}$ or $\alpha$-tocopherol and tocotrienol function as important antioxidants by taking unpaired electrons from the body's excess free radicals, even though in the above reactions vitamins $C$ and $E$ themselves become free radicals by gaining an unpaired electron. Due to their chemical structure they become weaker free radicals than the ones they have earlier reacted or oxidized.. The beneficial effects of these compounds are attributed to the antioxidant and free radical scavenging properties of their various components such as polyphenols and flavonoids. (Bolarin et al 2016). 
Table 8. Blood catalase, GPXs, MDA and total antioxidant of hypercholesterolemia rats fed for 6 weeks on diets containing $10 \%$ of studied oils

\begin{tabular}{|c|c|c|c|c|c|c|c|c|}
\hline \multirow{3}{*}{ Treatments } & \multicolumn{2}{|c|}{$\begin{array}{c}\text { Catalase } \\
\text { (U/mI) }\end{array}$} & \multicolumn{2}{c|}{$\begin{array}{c}\text { GPXs } \\
\text { (U/mI) }\end{array}$} & \multicolumn{2}{c|}{ MDA (nmol/mI) } & \multicolumn{2}{c|}{$\begin{array}{c}\text { Total } \\
\text { antioxidant } \\
\text { (mM/L) }\end{array}$} \\
\cline { 2 - 9 } & \multicolumn{2}{|c|}{$\begin{array}{c}\text { Feeding period } \\
\text { (weeks) }\end{array}$} & \multicolumn{2}{|c|}{$\begin{array}{c}\text { Feeding period } \\
\text { (weeks) }\end{array}$} & \multicolumn{2}{c|}{$\begin{array}{c}\text { Feeding period } \\
\text { (weeks) }\end{array}$} & \multicolumn{2}{c|}{$\begin{array}{c}\text { Feeding period } \\
\text { (weeks) }\end{array}$} \\
\cline { 2 - 9 } & $\mathbf{0}$ & $\mathbf{6}$ & $\mathbf{0}$ & $\mathbf{6}$ & $\mathbf{0}$ & $\mathbf{6}$ & $\mathbf{6}$ \\
\hline N- control G 1 & $158.47^{\mathrm{a}}$ & $150.85^{\mathrm{a}}$ & $128.05^{\mathrm{a}}$ & $131.27^{\mathrm{bc}}$ & $7.44^{\mathrm{b}}$ & $7.09^{\mathrm{d}}$ & $1.72^{\mathrm{a}}$ & $1.76^{\mathrm{a}}$ \\
P- control G 2 & $120.54^{\mathrm{b}}$ & $96.51^{\mathrm{c}}$ & $105.96^{\mathrm{b}}$ & $85.49^{\mathrm{d}}$ & $11.94^{\mathrm{a}}$ & $17.19^{\mathrm{a}}$ & $0.97^{\mathrm{b}}$ & $0.88^{\mathrm{d}}$ \\
G 3 & $122.05^{\mathrm{b}}$ & $131.07^{\mathrm{b}}$ & $103.89^{\mathrm{b}}$ & $135.18^{\mathrm{b}}$ & $12.99^{\mathrm{a}}$ & $10.01^{\mathrm{c}}$ & $0.98^{\mathrm{b}}$ & $1.47^{\mathrm{b}}$ \\
G 4 & $120.89^{\mathrm{b}}$ & $133.34^{\mathrm{b}}$ & $104.89^{\mathrm{b}}$ & $141.74^{\mathrm{a}}$ & $11.49^{\mathrm{a}}$ & $9.99^{\mathrm{c}}$ & $0.97^{\mathrm{b}}$ & $1.54^{\mathrm{b}}$ \\
G 5 & $119.87^{\mathrm{b}}$ & $127.99^{\mathrm{b}}$ & $104.27^{\mathrm{b}}$ & $127.61^{\mathrm{c}}$ & $11.42^{\mathrm{a}}$ & $12.43^{\mathrm{b}}$ & $1.00^{\mathrm{b}}$ & $1.11^{\mathrm{c}}$ \\
\hline
\end{tabular}

Means with the same letters in the same column are not significantly different at $5 \%$ level

These results are in agreement with Badrian et al (2006), they found that dietary RPO supplementation was able to increase GPX and other antioxidant enzyme activity in myocardial tissue. They suggested that this increase was followed by reduced oxidative stress in an ischaemia/reperfusion model. Dietary RPO supplementation increases the expression of GPX 4 mRNA. The increasing of GPXs activity was due to up regulation of the GPX 4 gene by RPO supplementation. This may be due to the increased amount of antioxidants provided in the diet by RPO supplementation, which should lead to improvement of intracellular oxidative stress status.

\section{REFERENCES}

Aebi, H. 1984. Catalase in vitro. Method Enzymol. 105,121-126.

Allain, C.C., Poon, L.S., Chan, C.S., Richmond, W. and Fu, P.C. 1974. Enzymatic determination of total serum cholesterol. Clin. Chem. 20, 470-475.

AOAC 2010. Official Methods of Analysis of Association of Official Analytical Chemists. 19th ed., published by A.O.A.C., Arlington, VA.

Badrian, B., Casey, T.M., Lai, M.C., Rakoczy, P.E., Arthur, P.G. and Bogoyevitch, M.A. 2006. Contrasting actions of prolonged mitogen- activated protein kinase activiation on cell survival. Biochem. Biophys. Res. Comm. 345, 843-850.

Barham, D. and Trinder, P. 1972. Determination of Uric acid using enzymatic colorimetric method, Analyst. 97, 142-145
Bolarin, D.M., Ekpe, E.L., Saidu, K. and Eyam, E.S. 2016. Overview of Foods with antoxidant effects clinica relevance. Euro. J. Food Sci. and Technol. 4(2), 1-9.

Dauqan, E., Sani, H.A., Abdullah, A. and Kasim, Z.M. 2011. Effect of Different Vegetable Oils (Red Palm Olein, Palm Olein, Corn Oil and Coconut Oil) on Lipid Profile in Rat. Food and Nutrition Sciences. 2, 253-258.

Doumas, B.T., Watson, W.A. and Biggs, H.G. 1971. Albumin standards and the measurement of serum albumin with bromocresol green. Clin. Chim. Acta., 31(1), 87- 96.

El-Hadad, N., Abou-Gharbia, H.A., Abd El-Aal, M.H. and Youssef, M.M. 2010. Red Palm Olein: Characterization and Utilization in Formulating Novel Functional Biscuits. J. Am. Oil Chem. Soc. 87, 295-304.

Fattore, E. and Fanelli, R. 2013. Palm oil and palmitic acid: a review on cardiovascular effects and carcinogenicity. Inter. J. Food Sci. Nutr. 64(5), 648-659.

Fawcet, J.K. and Scott, J.E. 1960. A rapid precise method for the determination of urea. J. Clin. Pathol. 13, 156-159.

Friedewald, W.T., Levi, R.I. and Fredrickson, D.S. 1972. Estimation of the concentration of low density lipoproteins cholesterol in plasma without use of the ultracentrifuge. J. Clin. Chem. 18, 499-502.

Hare, R.S. 1950. Endogenous creatinine in serum and urine. P.S.E.B.M. 74(7), 148-151.

Jeger, R. and Dieterle, T. 2012. Statins: have we found the Holy Grail? Swiss Med Wkly.142, 14. 
Koracevic, D., Koracevic, G., Djordjevic, V., Andrejevic, S. and Cosic, V. 2001. Method for the measurement of antioxidant activity in human fluids. J. Clin Pathol. 54, 356-361.

Lopez-Virella, M.F., Stone, P., Ellise S. and Collwell, J.A. 1977. Cholesterol determination in high density lipoproteins separated by three different methods. Clin. Chem. 23(5), 882-885.

Mamat, H., Nor Aini, I., Said, M. and Jamaludin, R. 2005. Physicochemical characteristics of palm oil and sunflower oil blends fractionated at different temperatures. Food Chem. 91, 731736.

Mancini, A., Imperlini, E., Nigro, E., Montagnese, C., Daniele, A., Orrù, S. and Buono, P. 2015. Biological and nutritional properties of palm oil and palmitic Acid: effects on health. Molecules. 20, 17339-17361.

Mossa, A.H. and Abbassy, M. 2012. Adverse hematological and biochemical effects of certain formulated insecticides in male rats. Res. J. Environ. Toxicol. 6, 160-168.

Nagendran, B., Unnithan, U.R., Choo, Y.M. and Sundram, K. 2000. Characteristics of red palm oil, a carotene- and vitamin E-rich refined oil for food uses. Food Nutr. Bull. 2, 189-194.

Ng, J. H. and Tan, B. 1988. Analysis of Palm Oil Carotenoids By HPLC with Diode- Array Detection. J. of Chromatographic Sci. 26, 463-469.

Ngondi, J.L., Mbouobda, H.D., Etame, S. and Oben, J. 2005. Effect of Irvingia gabonensis Kernel Oil on Blood and Liver Lipids on Lean and Overweight Rats. J. Food Technol. 3(4), 592-594.

Olorunnisola, O.S., Bradley, G. and Afolayan, A.J. 2012. Protective Effect of T. violacea Rhizome Extract Against Hypercholestero-lemiaInduced Oxidative Stress in Wistar Rats. Molecules. 17(5), 6033- 6045.

Paglia, D.E. and Valentine, W.N. 1967. Studies on the quantitative and qualitative characterization of erythrocyte glutathione peroxidase. The J. of Laboratory Clinical Medicine. 70(1), 158-169.
Plozza, T., Trenerry, V.C. and Caridi, D. 2012. The simultaneous determination of vitamins $A$; $E$ and $\beta$-carotene in bovine milk by high performance liquid chromatography-ion trap mass spectrometry (HPLC-MSn). J. Food Chem., 134, 559-563.

Prasanth Kumar, P.K. and Gopala Krishna, A.G. 2014. Physico-chemical characteristics and nutraceutical distribution of crude palm oil and its fractions. Grasas Y Aceites. 65(2), e018. https://doi.org/10.3989/gya.097413

Rahman, T., Ismail, H., Towhidul, I.M.M. and Hossain, U.S. 2012. Oxidative stress and human health. Advances in Bioscience and Biotechnology. 3, 997-1019.

Reitman, A. and Frankel, S. 1957. A colorimetric method for the determination of serum glutamic oxaloacetic and glutamic pyruviec transaminase. Amer. J. Clin. Path. 28, 56-63.

Sambanthamurthi, R., Sundram, K. and Tan, Y. 2000. Chemistry and biochemistry of palm oil. Progress in Lipid Research 39, 507-558.

SAS, 1995. Statistical Analysis System ( $\left.5^{\text {th }} \mathrm{Ed}\right)$. Institute Incc. Gary. NC, U.S.A. SECEX (Secretaria do Comercio Exterior)MDIC (2002).

Satoh, K. 1978. Serum lipid peroxide in cerebrovascular disorders determined by a colorimetric method. Clin. Chim. Acta. 90, 37-43.

Schermer, S. 1967. The blood morphology of laboratory animals. Lengmans; Green and Co. Ltd. $350 \mathrm{p}$.

Shahidi, F. and De Camargo, A.C. 2016. Tocopherols and tocotrienols in common and emerging dietary sources: Occurrence, applications, and health benefits. Inter. J. Molec. Sci. 17(10), 1-29.

Small, D.M., Coombes, J.S., Bennett, N., Johnson, D.W. and Gobe, G.C. 2012. Oxidative stress, anti-oxidant therapies and chronic kidney disease. Nephrology. 17(4), 311-321.

Stevens, L.A., Coresh, J., Greene, T. and Andrew, S.L. 2006. Assessing kidney function measured and estimated glomerular filtration rate. N. England J. Medic. 354, 2473-2483.

Sutapa, M. and Analava, M. 2009. Health effects of Palm Oil. J. Hum. Ecol. 26(3), 197-203. 



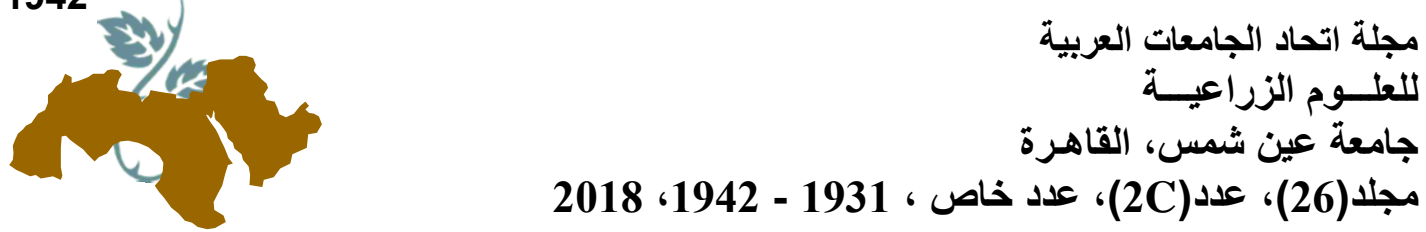

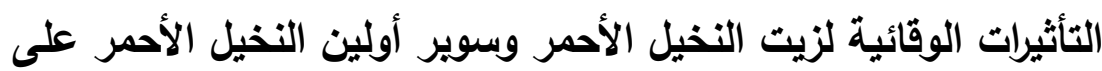

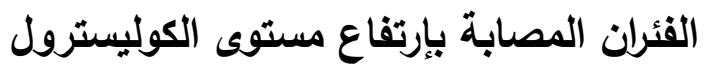

$[142]$

\author{
هدى حسن إبراهيم محمد 1 - ماجده حبيب علام² - نسرين محمد نبيه يسن2 - \\ صائب عبد المنعم حافظ 1 دانب علان \\ 1- قسم الاغذية الخاصة والتغذيـة - معهد بحـوث تكنولوجيا الأغذيــة - مركز البحوث الزراعية - جيزة - مصر \\ 2- قسم علوم الأغذية - كلية الزراعة - جامعة عين شمس - ص.ب. 68 حدائق شبرا 11241- القاهرة - مصر
}

الججموعة الخامسة فقد نم تغذيتها على نفس عليقة

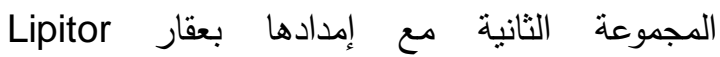
Atorvastatin الفئران يوميا بإستخدام الانبوبه المعدية. وفيما ينعلق

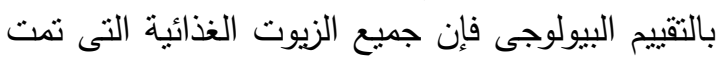

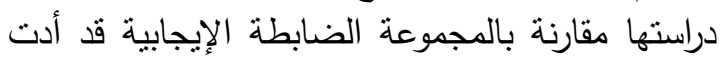

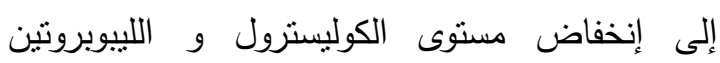
منخفض الكثافة فى السيرم وزيادة مستوى اللييوبروتين عالى الكثافة خلال فترة التجربة وبالتالى حدث الثين إنخفاض

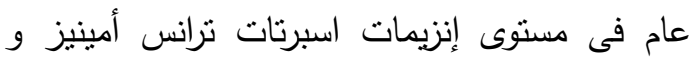
الانين ترانس أمينيز والالبيومين فى سيرم الفئران عند تغذيتها على زيت النخيل الأحمر وسوبر أولين الألين النخيل

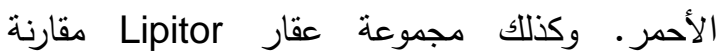
بالمجموعة الضابطة الإيجابية وكذلك لوحظ إلكار إنخفاض

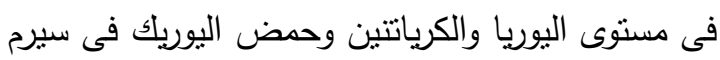

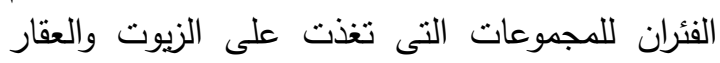

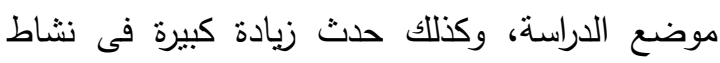

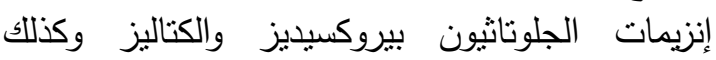

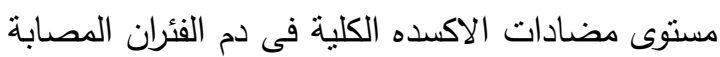
بإرتفاع مستوى الكوليسترول فى الدم والتى تم تغذينئها

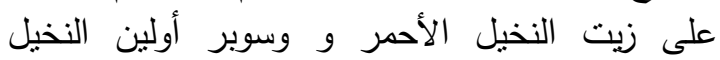

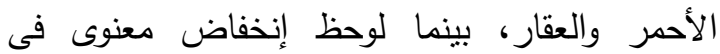
مستوى المالوندايالدهيد في بلازما الفئران.
الكلمات الدالة: زيت النجيل الأحمر، سوبر أولين

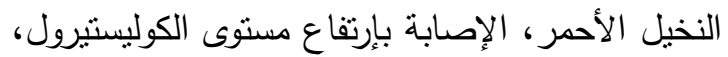

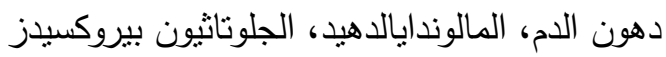

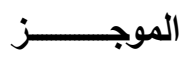

أجرى البحث لدراسة نأثثر زيت النخيل الأحمر

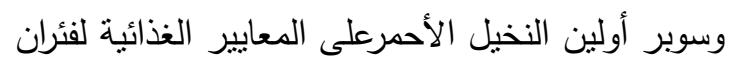

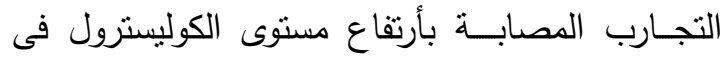

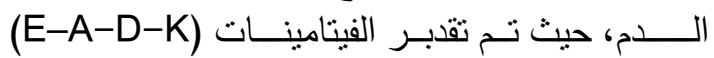
والبيتاكاروتين بإستخدام جهاز الكروماتوجرافى السائل

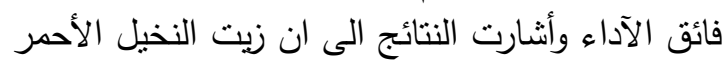

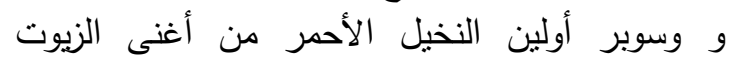

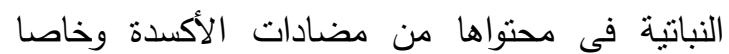

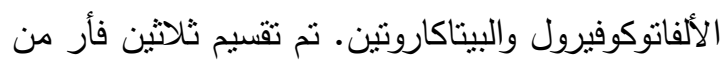

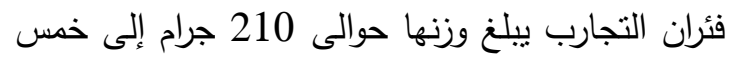

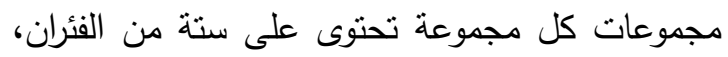

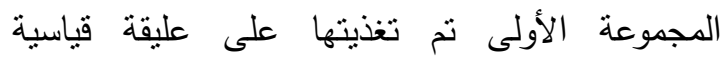

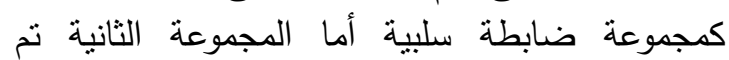

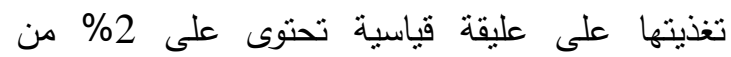

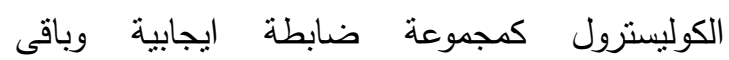
المجموعات تم تغذيتها على نفس العليقة مع استبدال زيت الذرة بزيت النخيل الأحمر للفجموعة الثالثة وبسوبر أولين النخيل الأحمر للمجموعة الرابعة أما لألة لإلة 
1942

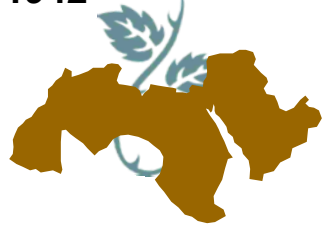

مجلة اتحاد الجامعات العربية

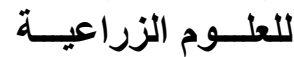

جامعة عين شمس، القاهرة

مجلا(26)، عدد(2C)، عدد خاص الثرة ، 1931 - 1942، 2018

تحكيم: ا.د عــادل زكسى بديـع

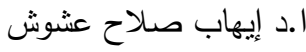

